\title{
THE INFLUENCE OF LEARNING BASED MULTIMEDIA PRESENTATION AND LEARNING MOTIVATION ON RECEIVING INFORMATION ABILITY
}

\author{
LUKMANULHAKIM, ST., M.PD .
}

\begin{abstract}
ABSTRAK
This study aims to investigate the influence of learning based multimedia presentation and learning motivation on receiving information ability by third grade of elementary school in Pontianak.

The research design use $2 \times 2$ factorial. The sampling technique which population sampling is 60 students in 2 class.

Liliefors test was used to test data normality. Barlett test of Chi Square statistic was used for testing data homogeneity. Analysis of variance (ANAVA) was used to analyze data followed by two line.

The finding in this research are: (1) Receiving information ability on learning with animation class have superior or higher than dari Receiving information ability on learning with image class; (2) There are interaction on learning based multimedia presentation with learning motivation on receiving information ability; (3) Student have great learning motivation and learning with animation have superior than great learning motivation and learning with image; (4) Student have low learning motivation used learning with image have superior than student have low motivation used leaning with animation.

The result of this research are expected to have implications for learning in classrooms for teacher and student.
\end{abstract}

\section{PENDAHULUAN}

Penerimaan informasi pada manusia dipengaruhi oleh indra. Optimalisasi indra dapat dilakukan dengan memanfaatkan media yang diterima indra sebagai stimulus yang berupa informasi dari lingkungan sekitar. Banyaknya media akan ditangkap oleh masing-masing indra dipengaruhi oleh penggunaan media. Dalam pembelajaran di kelas banyak guru hanya mengoptimalkan indra penglihatan saja dalam bentuk visual baik secara verbal maupun gambar atau hanya indra pendengaran saja yang bersifat auditorik verbal maupun suara suatu kejadian tertentu. Bahkan banyak guru yang hanya menerangkan dengan tulisan di papan tulis maupun tekstual menurut buku

${ }^{1}$ Lukmanulhakim adalah dosen Prodi PAUD FKIP Untan 
pelajaran. Dengan metode pembelajaran yang digunakan guru di atas, penerimaan informasi hanya terpada pada satu indra saja sehingga penerimaan informasi tidak menyeluruh dan melelahkan.

Mengacu pada usia masuk sekolah, siswa kelas III SD kurang lebih berada pada usia 8 tahun. Dimana, usia 8 tahun masih berada pada masa usia dini. Masa usia dini merupakan masa keemasan, dimana semua aspek perkembangan (fisik, kognitif, sosial-emosional) masih terus berkembang. Otak mereka akan terus berkembang untuk menerima informasi sebanyakbanyaknya. Oleh karena itu, kesempatan belajar mereka harus terpenuhi dalam proses belajar mengajar.

Materi pelajaran merupakan informasi yang disampaikan oleh guru sebagai sumber dan siswa sebagai tujuannya. Informasi yang disampaikan diharapkan dapat maksimal terserap oleh siswa sehingga dapat meningkatkan hasil belajarnya. Harapan inilah yang menjadi keinginan guru dan siswa pada setiap proses belajar mengajar dilakukan.

Untuk mencapai harapan itu tentunya perlu usaha yang maksimal dilakukan oleh semua pihak. Perlu adanya inovasi dari guru dalam mengembangkan metode belajar dan meningkatkan wawsan siswa mereka sehingga harapan yang diinginkan dapat tercapai. Rumusan masalah dari penelitian ini mencakup 3 hal berikut.

1. Apakah terdapat pengaruh pembelajaran berbasis presentasi multimedia terhadap kemampuan menerima pada anak Kelas III SD?

2. Apakah terdapat pengaruh motivasi belajar terhadap kemampuan menerima pada anak Kelas III SD?

3. Apakah terdapat pengaruh interaksi antara pembelajaran berbasis presentasi multimedia dan motivasi belajar terhadap kemampuan menerima informasi pada anak Kelas III SD?

\section{KAJIAN TEORI}

Penerimaan informasi merupakan hasil dari proses informasi dan proses informasi merupakan bagian dari kemampuan kognitif. Slavin menyatakan teori pembelajaran kognitif yang menjelaskan pengolahan, penyimpanan, dan penarikan kembali pengetahuan dalam pikiran ${ }^{2}$.

Proses informasi tersebut terjadi pada otak manusia. Proses informasi di dalam otak manusia merupakan proses belajar. Gagne menyatakan bahwa belajar adalah sesuatu yang terjadi di dalam benak seseorang di dalam otak ${ }^{3}$. Sejalan dengan Gagne, Woolfolk menyatakan pemrosesan informasi seperti

\footnotetext{
${ }^{2}$ Robert E. Slavin, Psikologi Pendidikan. Alih bahasa: (Jakarta: Indeks, 2008) p. 219

${ }^{3}$ Robert M. Gagne, Prinsip-prinsip Belajar untuk Pengajaran. Alih bahasa: Abdillah Hanafi dan Abdul Manan (Surabaya: Usaha Nasional, 1988) p. 23
} 
komputer, memasukkan informasi, melakukan berbagai operasi pada informasi itu untuk mengubah bentuk dan isinya, menyimpan informasi tersebut, mengambilnya lagi saat dibutuhkan, dan menciptakan berbagai respon terhadapnya ${ }^{4}$. Kemampuan terbaik setiap orang akan dipengaruhi oleh kemampuannya dalam mengatur pikirannya dengan cara memanipulasi dan merancang strateginya sehingga memperoleh makna dari informasi yang diterima karena pikiran manusia adalah suatu penciptaan makna ${ }^{5}$.

Proses yang terjadi merupakan transformasi dari informasi yang diterima sampai disimpan atau di keluargan kembali. Gagne menyatakan bahwa proses-proses yang harus disusun seseorang dalam rangka mejelaskan gejala belajar adalah proses yang menunjukkan transformasi "masukan" menjadi "keluaran" seperti yang terjadi pada komputer ${ }^{6}$.

Mempertegas pernyataan di atas, Sternberg menyatakan bahwa teori proses informasi adalah mengkhususkan makna dalam menjelaskan peran penyandian dan strategi konsepsi. Menurutnya ada 3 tipe dari komponen pemrosesan informasi yaitu, performance components, knowledge acquisition components, metacomponents ${ }^{7}$.

Pertama, performance components merupakan proses informasi secara khusus/bagian-bagian yaitu dengan penyandian, kesimpulan, pemetaan dan aplikasi. Kedua, knowledge acquisition components merupakan proses informasi dengan melakukan pemilihan terhadap sandi-sandi, mengkombinasikannya, dan memilih pasangannya. Ketiga, metacomponent merupakan komponen yang digunakan dalam strategi merekonstruksi informasi. Sejalan dengan itu, Siegler menyatakan bahwa anak mengkonstruksi strategi baru dan mengeneralisasinya ke dalam situasi yang lebih baru ${ }^{8}$. Selanjutnya, Ia menyatakan terdapat tiga mekanisme kerja bersama-sama menciptakan perubahan-perubahan pada keahlian kognitif anak, yaitu: penyandian, otomatisasi, dan konstruksi strategis ${ }^{9}$. Pertama, penyandian adalah proses informasi mencapai memori. Perubahan-perubahan dalam keahlian kognitif anak bergantung pada meningkatnya keahlian menyandikan informasi yang relevan, sekaligus mengabaikan informasi yang tidak relevan. Kedua, otomatisasi mengacu pada kemampuan memproses informasi dengan usaha minimal atau tanpa usaha sama sekali. Saat seorang anak telah mampu

\footnotetext{
${ }^{4}$ Anita Woolfolk, Educational Psychology. Alih bahasa: H. Prayitno Sutjipto dan Sri Mulyantini Sutjipto (Yogyakarta: Pustaka Pelajar, 2008) p.7

${ }^{5}$ Robert E. Slavin, Psikologi Pendidikan. Alih bahasa: (Jakarta: Indeks, 2008) p. 218

${ }^{6}$ Robert M. Gagne, Prinsip-prinsip Belajar untuk Pengajaran. Alih bahasa: Abdillah Hanafi dan Abdul Manan (Surabaya: Usaha Nasional, 1988) p.28

${ }^{7}$ Robert S. Siegler, Children Thinking (New Jersey: Prentice Hall, 1991) p. 70

${ }^{8}$ Ibid. p. 89

${ }^{9}$ John W. Santrock, Perkembangan Anak (Jakarta: Erlangga, 2007) p. 279
} 
membaca suatu kata dengan baik, mereka tidak membaca huruf demi huruf melainkan menyadikan keseluruhan kata. Akibatnya, pemrosesan informasi menjadi lebih otomatis. Ketiga, konstruksi strategi adalah pembentukan prosedur baru pemrosesan informasi.

Rousseau menyatakan bahwa alam seperti guru yang tersebunyi yang mendorong anak mengembangkan kemampuan berbeda-beda di tingkat pertumbuhan yang berbeda ${ }^{10}$. Ia menekankan pada proses interaksi anak dengan alam. Ia juga menyatakan pada usia 2 sampai 12 tahun anak mulai memiliki sejenis rasio tertentu, namun bukan rasio yang sanggup menghadapi kejadian-kejadian yang jauh dan abstraksi. Lebih tepatnya jenis rasio ini terkait langsung pada gerakan tubuh dan indera ${ }^{11}$.

Kemudian informasi dari lingkungan luar diasumsikan menjadi masukan dalam perseptual memori ${ }^{12}$. Pada proses masukan inilah terjadi proses penyandian dari bentuk kejadian menjadi "file-file" di dalam memori. file-file tersebut akan disimpan dan dikeluarkan apabila dibutuhkan. Memori inilah menurut Lerner didasarkan atas sekumpulan ide atau kejadian yang terjadi secara bersama-sama dalam waktu tertentu ${ }^{13}$. Solso, Maclin \& Maclin menyatakan kelupaan terjadi karena kegagalan penyandian dan mengacu pada kegagalan memasukkan materi ke dalam memori jangka panjang. Artinya proses mengingat dipengaruhi oleh proses penyandian yang dilakukan ketika informasi akan memasuki memori ${ }^{14}$. Johnson menyatakan bahwa perspektif kognitif pada ingatan memfokuskan pada prosesnya, bukan pada fisiologisnya. Salah satu teori utama proses mengingat adalah teori dua proses. Keduanya diketahui sebagai ingatan jangka pendek dan jangka panjang ${ }^{15}$.

Menurut teori perkembangan anak umumnya anak-anak tumbuh dan belajar dari dorongan pendewasaan batiniah dan keingintahuan mereka sehingga proses berpikir hanya didasarkan atas kemampuan independen dari proses penerimaan informasi. Namun, kemampuan ini saja menurut Vygotsky, tidak akan sanggup melangkah jauh. Untuk mengembangkan pikiran mereka seutuhnya, anak-anak juga perlu dilengkapi alat-alat intelektual yang

\footnotetext{
${ }^{10}$ William Crain, Teori Perkembangan. Alih bahasa: Yudi Santoso (Yogyakarta: Pustaka Pelajar, 2007) p. 18

${ }^{11}$ Ibid, p.19

${ }^{12}$ Camille B. Wortman and Elizabeth F. Loftus, Psychology (New York, USA: Alfred A. Knopf, Inc, 1985) p. 226

${ }^{13}$ Richard M. Lerner, dkk. 1986. Psychology. New York: Mac Millan Publishing Company, 1986) p. 209

${ }^{14}$ Robert L. Solso, Otto H. Maclin, M. Kimberly Maclin, Psikologi Kognitif (Jakarta: Erlangga, 2008) p. 217

${ }^{15}$ Gregory Johnson, Creating Powerful Memory, Alih bahasa: M. Jauhar (Jakarta: Prestasi Pustaka, 2009) p.64
} 
disediakan budaya mereka- peralatan seperti bahasa, sistem bilangan, tulisan, dan konsep-konsep ilmiah ${ }^{16}$.

Dari teori-teori di atas dapat disimpulkan proses informasi merupakan proses penerimaan informasi dari rangsangan hingga meresponnya. Proses informasi berjalan dari penerimaan, memanipulasi, memonitor dan merekonstruksinya guna menghasilkan informasi yang sama maupun lebih baik dari apa yang telah diterimanya. Proses yang terjadi merupakan transformasi dari informasi yang diterima sampai disimpan atau dikeluarkan kembali.

Menurut Santrock model dasar dari proses informasi berjalan dari kejadian, perhatian, penyandian, memori, proses berpikir, hingga ke respons. Alur informasi di awali dengan kejadian-kejadian yang diperoleh dari lingkungan maupun media. Kejadian ini biasanya terklasifikasi menjadi dua bentuk-bentuk dasar dari informasi yaitu kata-kata dan gambar. Bentuk-bentuk dasar informasi tersebut akan diterima oleh sensory memory melalui indra penglihatan dan pendengaran. Indra-indra tersebut akan memilah kata yang berbentuk suara maupun cetak dan gambar yang berbentuk cetak. Keberadaan indra mempunyai implikasi pendidikan penting ${ }^{17}$. Pertama, orang harus memberikan perhatian pada informasi kalau mereka ingin mengingatnya. Kedua, diperlukan waktu untuk membawa semua informasi yang dilihat dalam waktu singkat ke dalam kesadaran. Pemilahan pada sensory memory akan diteruskan ke memori kerja. Proses perpindahan dari sensori memori inilah terjadinya persepsi. Persepsi merupakan penafsiran seseorang tentang rangsangan.

Pada memori kerja informasi akan dipilah menjadi yang berbentuk suara dan gambar. Informasi yang berbentuk suara mengorganisir kata menjadi model verbal sedangkan informasi yang berbentuk gambar langsung diorganisir menjadi model pictorial. Kedua model ini akan berintegrasi. Dilakukan penyimpanan jika diperlukan pada memori jangka panjang.

Keberhasilan proses penerimaan informasi dilakukan dengan pengujian terhadap respon dari penerimaan informasi. Proses penerimaan informasi merupakan domain kognitif, Bloom ${ }^{18}$ dalam taksonominya menyatakan bahwa kognitif, meliputi pengetahuan dan pengembangan kemampuan intelektual yang terdiri dari pengetahuan, pemahaman, aplikasi, analisis, sistesis, dan evaluasi. Dari aspek-aspek tersebut hanya akan diujikan dua aspek yaitu mengetahui dan memahami. Aspek pengetahuan merupakan pengingatan

\footnotetext{
${ }^{16}$ William Crain, Teori Perkembangan. Alih bahasa: Yudi Santoso (Yogyakarta: Pustaka Pelajar, 2007) p. 375

${ }^{17}$ Robert E. Slavin, Psikologi Pendidikan. Alih bahasa: (Jakarta: Indeks, 2008) p. 220

${ }^{18}$ Bloom's Taxonomy of Learning Domains, http://www.nwlink.com/ donclark/hrd/bloom.html
} 
kembali atas data atau informasi. Aspek ini terdiri dari pengurutan dan penghubungan. Sedangkan aspek pemahaman merupakan pemahaman tentang makna terjemahan, dan penafsiran dari perintah dan masalah. Pemahaman terdiri dari mengklasifikasikan, dan menunjukkan.

Adanya informasi tentu dilakukan dengan komunikasi. Komunikasi dalam pembelajaran dibagi ke dalam dua tipe ${ }^{19}$. Pertama, Psychologycal Models, dimana menguji interaksi antara si belajar dan lingkungannya. Kedua, Engginering Models, dimana menjelaskan proses sebagai 'input', 'output', 'message" dan menggunakan analogi komunikasi dalam sirkuit elektronik. Dari kedua tipe di atas, penelitian ini lebih di arahkan pada tipe pertama dimana menguji interaksi antara sumber dan tujuan dan proses informasi. Namun, proses masukan, keluaran dan pesan tak dapat dilepaskan dari proses komunikasi itu sendiri. Proses penerimaan informasi akan di jelaskan pada sub bab lain, sedangkan pada bagian ini akan lebih membahas mengenai pesan atau informasi yang disampaikan dengan berbagai macam bentuk sesuai dengan media penerimanya melalui sensorik indra-indra manusia.

Konsep pengindraan manusia dalam proses informasi dipahami bahwa ada dua sistem ingatan manusia, satu untuk mengolah pesan yang berupa simbol-simbol verbal dan kemudian disimpan dalam bentuk proposisi image, dan yang lainnya untuk mengolah image non verbal yang kemudian di simpan dalam bentuk proposisi verbal.

Belajar menggunakan indra ganda memberikan banyak keuntungan. Seorang akan belajar lebih banyak dari pada penyusunan materi pelajaran disajikan hanya dengan stimulus pandang atau hanya stimulus dengar saja. Dale memperkirakan bahwa hasil belajar melalu banyak indra (televisi) mendapatkan $30 \%$ informasi dabandingkan dengan satu indra (membaca) yang memperoleh $10 \%$. Hasil belajar seseorang diperoleh mulai dari pengalaman langsung kenyataan yang ada di lingkungan kehidupan, kemudian melalui benda tiruan, dramatisasi, karyawisata, bercerita, diskusi, melihat lokasi, melihat demonstrasi, melihat bsebuah kebiasaan, menonton televisi, melihat gambar, mendengar kata, dan membaca. Dasar pengembangan kerucut di bawah ini bukanlah tingkat kesulitan, melainkan tingkat keabstrakan-jumlah jenis indra yang turut serta selama penerimaan informasi.

\footnotetext{
${ }^{19}$ Romiszowski, The Selection and Use of Instructional Media (Londong: Kogan Page, 1988) p. 3
} 


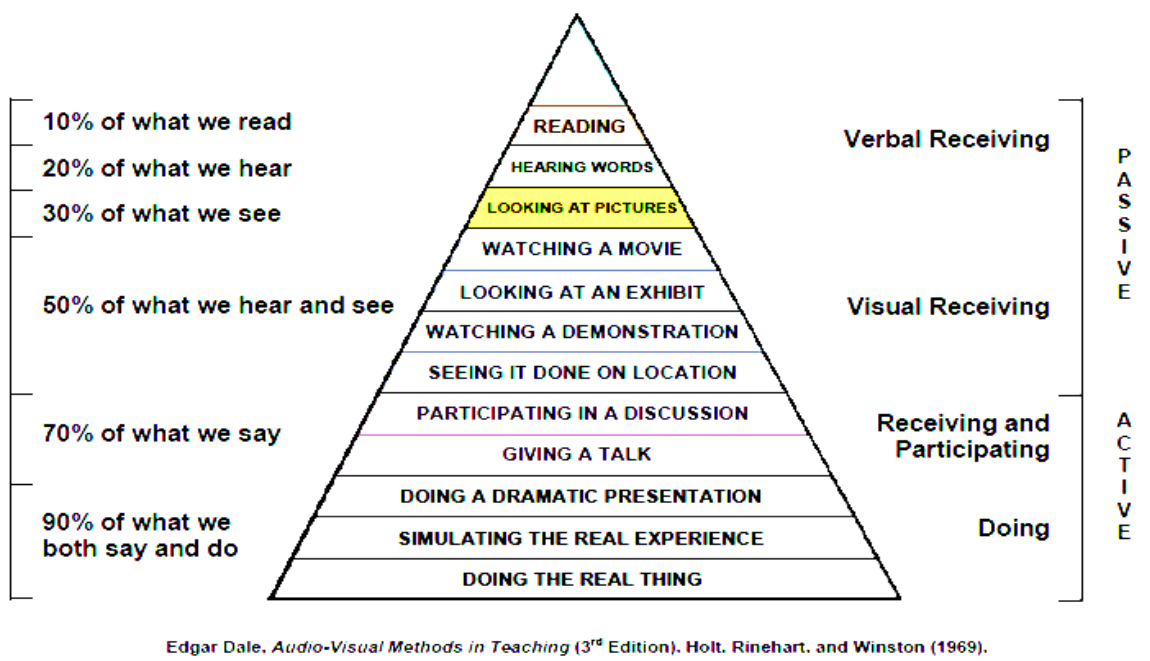

Gambar 1. Kerucut Pengalaman Edgar Dale

Multimedia secara etimologi didasarkan dari dua kata yaitu multi dan media. Multi diartikan sebagai banyak atau majemuk, sedangkan media sendiri berasal dari kata medium yang secara harfiah berarti perantara atau pengantar. Medoe adalah perantara atau pengantar pesan dari pengirim. Sadiman, dkk menyatakan bahwa media merubakan bentuk jamak dari medium yang secara harfiah berarti perantara atau pengantar ${ }^{20}$.

Memahami definisi multimedia secara keseluruhan tentunya lebih kompleks. Banyak para pakar telah mendifinisan multimedia secara umum diantaranya konsep multimedia didefinisikan oleh Haffost (dalam Feldmans, 1994) sebagai suatu sistem komputer yang terdiri dari hardware dan software yang memberikan kemudahan untuk menggabungkan gambar, video, fotografi, grafik dan animasi dengan suara, teks, dan data yang dikendalikan dengan program komputer ${ }^{21}$. Sejalan dengan hal tersebut Arsyad menyatakan bahwa multimedia merupakan penggunaan lebih dari satu media yang bisa berupa teks, grafik, animasi suara dan video ${ }^{22}$.

Romiszowski menyatakan multimedia sebagai "The instructional package many include programmed texts, model, complex training device or

\footnotetext{
${ }^{20}$ Arief S. Sadiman, R. Rahardjo, Anung Aryono, Rahardjiti, Media Pendidikan (Jakarta: Rajawali Pers, 2009) p.6

${ }^{21}$ Munir, Kurikulum berbasis Teknologi Informasi dan Komunikasi (Bandung: Alfabeta, 2008) p.233

${ }^{22}$ Azhar Arsyad, Media Pembelajaran (Jakarta: Rajawali Pers, 2009) p. 170
} 
apparatus, slide, film, and always full teacher notes ${ }^{23}$ ". Artinya banyaknya media pembelajaran yang dibungkus menjadi satu kesatuan. Multimedia adalah "the use of several different media to convey information (text, audio, graphics, animation, video, and interactivity) ${ }^{24}$. Multimedia juga merupakan media komputer. Multimedia merupakan penggunaan komputer untuk menampilkan dan mengkombinasikan text, graphics, audio, video dan animasi dengan menggunakan links dan tools yang memungkinkan pemakai untuk melakukan navigasi, berinteraksi, membuat, dan berkomunikasi ${ }^{25}$.

Multimedia pada penelitian ini sedikit lebih sempit dari beberapa pemaparan definisi dari para ahli di atas. Peneliti mengambil sebagian dari peran multimedia dalam pembelajaran yaitu sebagai media penyampaian pesan atau biasa disebut multimedia presentasi materi. Mayer menyatakan proses multimedia dalam pembelajar bisa dipandang sebagai akuisisi informasi (kendaraan pengiriman informasi) atau sebagai konstruksi pengetahuan (menciptakan penalaran) $^{26}$. Robin dan Linda menyatakan multimedia sebagai Alat yang dapat menciptakan presentasi yang dinamis dan interaktif yang mengkombinasikan teks, grafik, animasi, audio dan video $^{27}$. Munadi menyatakan multimedia presentasi digunakan untuk menjelaskan materi-materi yang sifatnya teoritis digunakan dalam pembelajaran klasikal, baik untuk kelompok kecil maupun besar. ${ }^{28}$ Smaldino, Lowther, dan Russell menyatakan seorang pengajar memberikan sebuah presentasi yang mungkin berupa pertanyaan yang dapat secara sukarela langsung dijawab ${ }^{29}$. Mayer lebih fokus dan spesifik tentang penelitiannya menggunakan multimedia sebagai presentasi. Ia menggunakan multimedia prsentasi sebagai penyajian pesanpesan yang melibatkan kata-kata dan gambar-gambar yang ditujukan untuk meningkatkan pembelajaran ${ }^{30}$.

Dari uraian para ahli tentang multimedia sebagai media presentasi di atas diperoleh pemahaman bahwa multimedia sebagai penyampai, perantara maupun pengantar informasi atau pesan dari sumber (pengajar) kepada si belajar menggunakan banyak media. Secara umum penggunaan multimedia

\footnotetext{
${ }^{23}$ A. J. Romiszowski, The Selection and Use of Instructional Media (Londong: Kogan Page, 1988) p. 251

${ }^{24}$ Multimedia, http://www.wordiq.com/definition/Multimedia 19/10/2010

${ }^{25}$ Multimedia, http://202.91.15.14/upload/files/9055_01-Pengantar_MULTIMEDIA.pdf $19 / 10 / 2010$

${ }^{26}$ Richard E. Mayer, Multimedia Learning (Yogyakarta: Pustaka Pelajar, 2009) p. 1

${ }^{27}$ Multimedia http://ryanvsp.multiply.com/journal/item/1 19.10/2010

${ }^{28}$ Yudhi Munadi, Media Pembelajaran (Jakarta: Gaung Persada Press, 2008) p. 148

${ }^{29}$ Sharon E. Smaldino, Deborah L. Lowther, James D. Russel, Instructional Technology and Media for Learning (New Jersey, USA: Pearson Prentice Hall, 2008) p. 24

${ }^{30}$ Richard E. Mayer, Multimedia Learning (Yogyakarta: Pustaka Pelajar, 2009) p. 3
} 
presentasi memberikan informasi berupa gambar-gambar dan kata-kata yang disajikan dengan berbagai bentuk. Multimedia juga merupakan pengajaran dan pembelajaran yang efektif dan efisien berdasarkan kemampuannya menyentuh berbagai panca indra: penglihatan, pendengaran dan sentuhan.

Penelitian ini akan menggunakan dua presentasi multimedia yaitu animasi (gambar bergerak) dan gambar (gambar diam) dengan karakteristik sebagai berikut.

a. Animasi atau biasa disebut gambar bergerak merupakan bentuk multimedia presentasi yang mengkombinasikan gambar dan suara ${ }^{31}$. Model ini menggunakan kombinasi slide dan suara sebagai narasipenjelasan- dari gambar.

b. Gambar (gambar diam) merupakan objek gambar biasa berbentuk slide. Bentuk gambar dapat secara tunggal maupun kombinasi ${ }^{32}$. Pada bagian ini penjelasan gambar berbentuk ilustrasi tulisan pada gambar.

Kedua model presentasi multimedia di atas akan disajikan pada anak sebagai media pembelajaran di kelas.

\begin{tabular}{|l|l|l|}
\hline \multirow{2}{*}{ KARAKTERISTIK } & \multicolumn{2}{|c|}{ JENIS MEDIA } \\
\cline { 2 - 3 } & \multicolumn{1}{|c|}{ ANIMASI } & \multicolumn{1}{c|}{ GAMBAR } \\
\hline \multirow{4}{*}{ KEUNTUNGAN } & - Bergerak & - Dapat langsung disiapkan \\
& - Berproses & - Murah \\
& - Berdramatisasi & - Mudah digunakan \\
& - Potensi dalam pembelajarn sikap & - Sederhana dengan ide yang \\
& - Dapat membatu pemecahan & kompleks \\
\hline \multirow{3}{*}{ KETERalah } & - Menyesuaikan zaman & - Dua dimensi \\
& - Kesalahan penapsiran & - Dilihat hanya sekelompok \\
& - Abstrak & kecil \\
& & - Terbatas \\
\hline
\end{tabular}

Tabel 1. Klasifikasi Jenis Media

Motif atau dalam bahasa Inggrisnya "motive", berasal dari kata "motion", yang berarti gerakan atau sesuatu yang bergerak. Istilah motif erat hubungannya dengan "gerak", yang dalam hal ini merupakan gerakan yang dilakukan oleh manusia atau disebut juga perbuatan atau tingkah laku. Ilmu psikologis mendefinisikan motif sebagai rangsangan, dorongan, atau pembangkit tenaga bagi terjadinya sesuatu tingkah laku. Feldman menyatakan

\footnotetext{
${ }^{31}$ Robert Heinich, Michael Molenda, James D. Russel, Instructional Media (Singapore: MacMillan, 1990) p. 191

32 Jerrold E. Kemp and Don C. Smellie, Planning, Producing, and Using Instructional Media (New York: Harper \& Row, 1989) p. 47
} 
motif sebagai "desires goals that prompt behavior"," artinya perilaku di dasarkan atas keinginan untuk mencapai tujuan, maka keinginan itulah sebagai motifnya.

Kata motif inilah yang kemudian dikenal dengan motivasi. Motivasi itu sendiri menurut Sarlito menunjukkan pada seluruh proses gerakan itu termasuk situasi yang mendorong tingkah laku ${ }^{34}$. Sejalan dengan pernyataan Sarlito, Carlson mendefinisikan motivasi sebagai "a driving force that moves us to a particular action",35. Lerner menyatakan motivasi sebagai "the direction of behavior". Ia juga menjelaskan bahwa motivasi merupakan alasan seseorang atau binatang membuat tanggapan tertentu atau perubahan pada perilaku ${ }^{36}$. Richard Clark ${ }^{37}(2005)$ dalam motivasi untuk pembelajaran menerangkan bahwa perilaku motivasi meliputi kemauan berusaha, ketekunan dan pencarian tujuan secara aktif.

Alasan yang menjadi kunci dari motivasi sejalan dengan pengendali atau pengarah menurut Madsen. Madsen (1959) mendefinisikan motivasi sebagai "encompassing all the factors that arouse, sustain, and direct behavior toward attainment of some goal ${ }^{38}$. Memperkuat pernyataan di atas, Feldman juga menyatakan bahwa motivasi mengandung arti "trying to identify why people do the things they $\mathrm{do}^{\mathbf{3 9}}$. Mendukung teori-teori di atas para ahli psikologi mempelajari motivasi sebagai "concerned with the forces that direct future behavior" ${ }^{\text {"40 }}$.

Motivasi adalah poin penting dalam mengendalikan perilaku. Feldman menyatakan bahwa motivasi tidak dapat dipisahkan dari tindakan ${ }^{41}$. Sehingga dapat kita ambil kesimpulan bahwa setiap perilaku sebenarnya tak terlepas dari motivasi apa yang melatarbelakanginya. Sejalan dengan pernyataan tersebut McGaugh, Thomson dan Nelson juga menyatakan bahwa "motivation is the fundamental driving thrust that general behavior ${ }^{42, " . ~ M o t i v a s i ~ m e n j a d i ~ f a k t o r ~}$ yang secara langsung sebagai kekuatan perilaku manusia.

\footnotetext{
${ }^{33}$ Robert S. Feldman, Essentials of understanding Psychology (USA: McGraw Hill, 1989) p.239

${ }^{34}$ Sarlito W. Sarwono, Pengantar Umum Psikologi (Jakarta: Bulan Bintang, 2003) p.61

${ }^{35}$ Neilr Carlson, Psychology (Massachusets, USA: Allyn And Bacon, 1987) p.404

${ }^{36}$ Richard M. Lerner, dkk, Psychology (New York: Mac Millan Publishing Company, 1986)p. 277

${ }^{37}$ Richard Clark, http://gamepedagogic.wordpress.com/2009/04/07/pemodelan-pengukurankemauan-berusaha-berdasarkan-metode-lvq-dalam-permaianan-pendidikan/

${ }^{38}$ Camille B. Wortman and Elizabeth F. Loftus, Psychology (New York, USA: Alfred A. Knopf, Inc, 1985) p.305

${ }^{39}$ Robert S. Feldman, Essentials of understanding Psychology (USA: McGraw Hill, 1989) p.239

${ }^{40}$ Ibid p.239

${ }^{41}$ Neilr Carlson, Psychology (Massachusets, USA: Allyn And Bacon, 1987)p.405

${ }^{42}$ James L. McGaugh, Richard F. Thomson, Thimas O. Nelson, Psychology I: An Experimental Approach (California, San Fransisco: Albion Publishing Company, 1977) p.156
} 
Satu pendekatan terbaru memfokuskan motivasi pada peran pikiran, harapan, pemahaman sebagai sebab orang berperilaku ${ }^{43}$. Pernyataan di atas cukup menarik ketika di korelasikan dengan proses belajar. Dimana proses belajar merupakan proses pengolahan informasi dengan tujuan perubahan perilaku. Sedangkan proses pengolahan informasi itu sendiri merupakan aktifitas kognitif.

Carlson menyatakan belajar merupakan perubahan kekal yang secara relatif terjadi dalam setiap perilaku individu yang dihasilkan dari lingkungan ${ }^{44}$. Prosesnya adalah satu adaptasi, maka perubahan perilaku dihasilkan dari interaksi dengan lingkungan. Perilaku kita adalah sangat dipengaruhi oleh pengalaman kita. Belajar dapat kita adaptasi keperluan menyeluruh dari lingkungan kita, hal itu mungkin menjadi baik untuk memulai dengan sebuah perspektif biologis dari belajar ${ }^{45}$. Lerner mendukung pendapat di atas. Ia menyatakan bahwa.

Belajar merupakan perubahan perilaku sebagai konsekwensi dari pengalaman adalah sesuatu bagian yang sangat penting dalam pekerjaan aktivitas. Kemampuan ini untuk membantu kita ketika menemui masalah dan tantangan yang dihadapi dalam lingkungan. Oleh karena itu, kemampuan ini adalah sebuah adaptasi; itu adalah sesuatu yang mendukung kita untuk merubah karakteristik kita dalam merubah dunia kita. Ada banyak proses adaptasi yang terjadi dalam kehidupan manusia. Bagaimanapun belajar adalah hal terbesar adaptasi manusia karena belajar mengizinkan kita untuk merubah cara mana yang mungkin menyelesaikan masalah dan menemui tantangan dalam kehidupan ${ }^{46}$.

Teori-teori di atas memberikan pemahaman bahwa perubahan perilaku merupakan tujuan yang diharapkan dari proses belajar. Belajar merupakan suatu proses pengalaman beradaptasi dengan lingkungan. Belajar memberikan kesempatan kita untuk melakukan perubahan. Jika kita kembali pada teori motivasi, maka perilaku terjadi karena adanya dorongan. Motivasi belajar di dasarkan atas dua faktor, motivasi intrinsik dan ekstrinsik. Motivasi intrinsik adalah "refers to motivation to engage in an activity for its own sake" Motivasi intrinsik merupakan sesuatu yang dinikmati orang dan karena itu

\footnotetext{
${ }^{43}$ Robert S. Feldman, Essentials of understanding Psychology (USA: McGraw Hill, 1989) p.259

${ }^{44}$ Neilr Carlson, Psychology (Massachusets, USA: Allyn And Bacon, 1987) p.99

${ }^{45}$ James L. McGaugh, Richard F. Thomson, Thimas O. Nelson, Psychology I: An Experimental Approach (California, San Fransisco: Albion Publishing Company, 1977) p.189

${ }^{46}$ Richard M. Lerner, op.cit p.179

${ }^{47}$ Dale S. Schunk, Paul R. Pintrich, Judith L. Meece, Motivation in Education (New Jersey, USA: Pearson Education, 2008) p.236
} 
dirasakannya memberikan motivasi ${ }^{48}$. Motivasi intrinsik adalah kecenderungan alamiah untuk mencari dan menaklukkan tantangan ketika kita mengejar kepentingan pribadi dan menerapkan kapabilitas. Motivasi yang berhubungan dengan kegiatan yang memiliki reward sendiri ${ }^{49}$. Motivasi instrinsik diantaranya adalah, (1) Challenge (Tantangan): aktivitas yang menantang kemampuan siswa yang mungkin memotivasinya secara intrinsik; (2) Curiosity (Keingintahuan): kebebesan yang terjadi ketika menjadi sadar akan kekosongan informasi; (3) Control (pengawasan): mengawasi hasil akademis mereka; (4) Fantasy (Khayalan): belajar dapat ditingkatkan dengan berfantasi dan percaya simulasi dan permainan pikiran yang disampaikan dalam situasi yang tak nyata dan aktual.

Lawannya, Motivasi ekstrinsik adalah motivasi yang digunakan dalam sebuah aktivitas sebagai keinginan untuk dicari. Individu yang berkerja dimotivasi ekstrinsik dalam bertugas karena mereka percaya partisipasi itu akan menghasilkan penghasilan yang sangat diinginkan seperti penghargaan, hadia, hukuman, dan lain-lain.

Motivasi ekstrinsik merupakan imbalan untuk pembelajaran yang tidak melekat dalam bahan yang sedang dipelajari yang dapat berupa pujian, nilai, penghargaan, hadiah, atau yang berasan dari eksternal diri individu ${ }^{50}$. Motivasi ekstrinsik adalah melakukan sesuatu untuk mendapatkan nilai, menghindari hukuman, membuat guru senang, atau alasan lain yang hanya asedikit sekali hubungannya dengan tugas itu sendiri. Motivasi yang diciptakan oleh faktorfaktor eksternal seperti reward dan hukuman ${ }^{51}$.

\section{METODE PENELITIAN}

Penelitian ini dilakukan di Kota Pontianak, Kalimantan Barat. Sebagai sumber data adalah Sekolah Dasar Islam Terpadu Bina Empat Lima (SDIT Bina 45) Pontianak di kelas awal tepatnya pada Kelas III. Penelitian ini dilaksanakan pada bulan Desember 2010 - Februari 2011.

Penelitian ini dilaksanakan dengan pendekatan eksperimen untuk mengetahui pengaruh antara variabel terikat dan variabel bebasnya. Ary, Jakobs dan Razavieh menyatakan bahwa metode survai dalam penelitian

\footnotetext{
${ }^{48}$ Robert E. Slavin, Psikologi Pendidikan, Alih bahasa: Marianto Samosir (Jakarta: Indeks, 2009) p. 130

${ }^{49}$ Anita Woolfolk, Educational Psychology. Alih bahasa: Helly Prajitno S dan Sri Mulyantini S. (Yogyakarta: Pustaka Pelajar, 2009) p.188

50 Robert E. Slavin, Psikologi Pendidikan, Alih bahasa: Marianto Samosir (Jakarta: Indeks, 2009) p. 130

${ }^{51}$ Dale S. Schunk, Paul R. Pintrich, Judith L. Meece, Motivation in Education (New Jersey,

USA: Pearson Education, 2008) p.236
} 
dirancang untuk melukiskan keadaan sesuatu atau yang sedang terjadi pada saat penelitian berlangsung ${ }^{52}$.

Variabel terikat adalah kemampuan menerima informasi dan variabel bebasnya adalah pembelajaran berbasis multimedia presentasi dan motivasi belajar. Penelitian ini menggunakan metode eksperimen dengan desain factorial 2 × 2 sebagai berikut.

\begin{tabular}{|c|c|c|c|}
\hline \multirow{2}{*}{$B$} & \multicolumn{3}{|c|}{$\mathbf{A}$} \\
\cline { 2 - 4 } & \multicolumn{2}{|c|}{$\mathbf{A}_{1}$} & $\mathbf{A}_{2}$ \\
\hline $\mathbf{B}_{1}$ & $\mathbf{A}_{1} \mathbf{B}_{1}$ & $\neq$ & $\mathbf{A}_{2} \mathbf{B}_{1}$ \\
\hline $\mathbf{B}_{2}$ & $\mathbf{A}_{1} \mathbf{B}_{2}$ & $\neq$ & $\mathbf{A}_{2} \mathbf{B}_{2}$ \\
\hline
\end{tabular}

Gambar 2. Desain Faktorian 2 x 2

\section{Keterangan}

A : Pembelajaran berbasis multimedia

A $\quad$ : Gambar Diam

$\mathbf{A}_{2}$ : Gambar Animasi

B : Motivasi belajar

$\mathbf{B}_{\mathbf{1}} \quad$ : Motivasi rendah

$\mathbf{B}_{2} \quad$ : Motivasi tinggi

Populasi target adalah siswa SD kelas tiga di Kota Pontianak. Populasi terjangkau penelitian ini adalah siswa Kelas III SDIT Bina 45 Kota Pontianak yang berjumlah 63 siswa yang terbagi dalam 2 kelas. Sekolah tersebut dipilih setelah dilakukan observasi sebelumnya bahwa terdapat masalah pembelajarn sains di kelas.

Sampel diambil secara acak dan teknik sampling yang digunakan adalah multi stage random sampling berdasarkan rancangan faktorial $2 \times 2$. Dari dua kelas akan dipilih secara acak kelas yang menggunakan animasi atau gambar. Kemudian, dari kelas tersebut akan diambil secara acak masingmasing 30 anak. Jadi total sampel keseluruhan 60 anak dari dua kelas. Jumlah sampel diambil berdasarkan pengamatan absensi dan wawancara dengan guru kelas masing-masing bahwa kehadiran setiap harinya minimal 30 anak.

${ }^{52}$ Donald Ary, Luchy C. Jacobs, Asghar Razavieh, Pengantar Penelitian dalam Pendidikan Alih bahasa: Arief Furchan (Yogyakarta: Pustaka Pelajar, 2004) p. 39 
Teknik pengumpulan data menggunakan perangkat instrumen penelitian berupa angket motivasi belajar dan tes kemampuan menerima informasi. Sebelum di uji cobakan seluruh instrumen dikonsultasikan dengan pembimbing.

Proses kalibrasi instrumen dilakukan dengan menganalisis data hasil uji coba, untuk menentukan validitas butir dan reliabilitas instrumen. Validitas (kesahihan) tes dimaksudkan untuk mengetahui apakah alat ukur (instrumen) tersebut mampu mengukur data objek yang hendak di ukur. Validitas merupakan pengujian terhadap apa yang mesti diukur oleh tes dan seberapa cermat melakukan pengukurannya ${ }^{53}$

Validitas butir soal dalam penelitian ini diuji dengan cara mengkorelasikan skor butir dengan skor total instrumen. Validitas butir soal dikatakan tinggi jika skor butir berkorelasi positif yang tinggi dengan skor totalnya. Ary, Jacobs, Razavieh menyatakan validitas berhubungan dengan sejauh mana suatu alat mampu mengukur apa yang dianggap orang seharusnya di ukur oleh alat tersebut ${ }^{54}$. Analisis validitas yang dikenakan pada pengujian ini adalah analisis butir, yaitu menghitung koefisien korelasi antara skor butir parametrik soal tes dengan skor butir soal, maka data setiap butir instrumen tes kemampuan menerima informasi digunakan rumus koefisien "Korelasi Product Moment " Hasil perhitungan skor butir tes instrumen kemampuan menerima informasi dinyatakan valid apabila nilai $r_{\text {hitung }}>r_{\text {tabel }}$ pada taraf signifikansi $\alpha=0,05$.

Pada variabel Kemampuan Menerima Informasi dengan melakukan uji coba instrumen pada 19 siswa yang dihitung menggunakan rumus koefisien korelasi antara skor butir dengan skor total instrumen menggunakan rumus "Korelasi Point Biserial".

Berdasarkan kriteria yang digunakan yaitu kriteria yang digunakan jika $\mathrm{r}_{\text {hitung }}>\mathrm{r}_{\text {tabel }}$ dengan $\alpha=0,05$, maka butir valid, sedangkan jika $\mathrm{r}_{\text {hitung }}<\mathrm{r}_{\text {tabel }}$ dengan $\alpha=0,05$ butir tidak valid maka diperoleh hasil keseluruh ( 24 butir) butir soal memiliki nilai valid.

Pengujian validitas instrumen untuk variabel Motivasi Belajar dilakukan dengan menganalisis data hasil uji coba instrumen yang diberikan kepada 19 orang siswa. Menggunakan koefisien korelasi antara skor butir dengan skor total instrumen digunakan "Formula Product Moment” sebagai berikut:

\footnotetext{
${ }^{53}$ Hamzah B. Uno, Herminanto Sofyan, I Made Candiasa, Pengembangan Instrument Untuk Penelitian (Jakarta: Delima Press, 2001) p. 139

${ }^{54}$ Donald Ary, Luchy C. Jacobs, Asghar Razavieh, Pengantar Penelitian dalam Pendidikan. Alih Bahasa: Arief Furchan (Yogyakarta: Pustaka Pelajar, 2004) p. 293
} 
Kriteria yang digunakan untuk uji validitas butir adalah jika $\left.\mathrm{r}_{\text {hitung }}\right\rangle$ $\mathrm{r}_{\text {tabel }}$ dengan $\alpha=0,05$, maka butir valid, sedangkan jika $\mathrm{r}_{\text {hitung }}<\mathrm{r}_{\text {tabel }}$ dengan $\alpha=0,05$ butir tidak valid. Hasil perhitungan berdasarkan data uji coba, diperoleh 18 butir yang memiliki koefisien korelasi $\left(\mathrm{r}_{\text {hitung }}\right)$ lebih besar dari $\mathrm{r}_{\text {tabel }}=0,456$, maka butir tersebut valid. Terdapat 3 butir yang tidak valid $(5,13$, $18)$.

Selain mengukur kevalidan instrumen, perlu diukur pula reliabilitas untuk mengurangi pengaruh kesalahan acak terhadap instrumen. Reliabilitas berhubungan dengan kesalahan acak terhadap konsistensi skor ${ }^{55}$. Menurut Uno, Fofyan, Candiasa reliabilitas merupakan pengukuran untuk menghitung seberapa konsistensi skor tes dari satu pengukuran ke pengukuran berikutnya. Dengan demikian dapat disimpulkan bahwa reliabilitas ditujukan untuk mengetahui konsistensi dari instrumen.

Proses perhitungan reliabilitas menggunakan rumus Koefisien Alpha Cronbach diperoleh hasil bahwa pada variabel Kemampuan Menerima Informasi yang menggunakan rumus KR-20 diperoleh nilai reliabilitas instrumen adalah 0,887. Sedangankan untuk variabel Motivasi Belajar nilai reliabilitasnya dihitung menggunakan rumus yang sama diperoleh nilai reliabilitas butir instrumen adalah 0,85

Analisis data terdiri atas deskriptif dan analisis inferensial. Analisis deskriptif berupa penyajian daya dengan daftar distribusi frekuensi dan histogram, mean, simpangan baku. Untuk mempermudah memahami data, maka dilakukan kategorisasi terhadap data hasil penelitian ke dalam dua kategori, yaitu tinggi dan rendah, dengan asumsi baku data tersebut berdistribusi normal dengan 6 wilayah simpangan baku.

Pengujian analisis digunakan ANAVA dua arah. Penggunaan teknik ini didasarkan atas pertimbangan bahwa rancangan yang digunakan adalah faktorial $2 \times 2$. Oleh karena itu, ANAVA mengikuti distribusi F tersebut, maka sebelum dilakukan pengujian, terlebih dahulu dilakukan pengujian persyaratan analisis. Menurut Sudjana, ANAVA mensyaratkan data berdistribusi normal dan varian antar kelompok homogen.

Uji homogenitas varian dimaksudkan untuk menguji homogenitas varian antara kelompok-kelompok skor $\mathrm{Y}$ yang dikelompokkan berdasarkan kesamaan $\mathrm{X}_{\mathrm{i}}$. Pengujian homogenitas dilakukan dengan uji Barlett dengan distribusi chi-kuadrat $\left(\mathrm{x}^{2}\right)$. Kriteria pengujian adalah $\mathrm{H}_{0}$ terdapat kesamaan variansi (data homogen) jika $x^{2}$ hitung $<x^{2}$ tabel dalam taraf nyata $\alpha=0,05$

${ }^{55}$ Ibid, p. 312 
Setelah uji persyaratan dilakukan selanjutnya pengujian hipotesis dengan Analisis Varian (ANAVA) dua arah. Pengukuran diawali dengan menghitung Jumlah Kuadrat (JK) dan derajat kebebasan (db) sumber varian.

\section{HASIL DAN PEMBAHASAN PENELITIAN}

Diperoleh data hasil penelitian dari setiap variabel dan interaksinya sebagai berikut.

1. Data Kemampuan Menerima Informasi pada kelas dengan Multimedia Gambar Diam $\left(\mathrm{A}_{1}\right)$

Data Kemampuan Menerima Informasi pada kelas dengan Multimedia Gambar Diam secara keseluruhan merupakan skor yang diperoleh dalam penelitian dengan menyebarkan 24 butir instrumen dalam skala interval. Setelah dilakukan rekapitulasi data, maka diperoleh nilai tertinggi adalah 16,5 dan terendah adalah 10,9. Rata-rata hitung (mean) adalah 13,65 dengan standar deviasi 1,89 serta memiliki varian 3,58.

2. Data Kemampuan Menerima Informasi pada kelas dengan Multimedia Gambar Animasi $\left(\mathrm{A}_{2}\right)$

Data tentang Kemampuan Menerima Informasi pada kelas dengan Multimedia Gambar Animasi secara keseluruhan merupakan skor yang diperoleh dalam penelitian dengan menyebarkan 24 butir instrumen dalam skala interval. Setelah dilakukan rekapitulasi data, maka diperoleh skor tertinggi 19,2 dan terendah 10,8. Rata-rata hitung (mean) adalah 15,037 dengan standar deviasi 2,42 serta memiliki varian 5,84.

3. Data Kemampuan Menerima Informasi yang berada di kelas menggunakan Multimedia Gambar Diam yang memiliki Motivasi Belajar Rendah $\left(\mathrm{A}_{1} \mathrm{~B}_{1}\right)$

Data tentang Data Kemampuan Menerima Informasi yang berada di kelas menggunakan Multimedia Gambar Diam yang memiliki Motivasi Belajar Rendah secara keseluruhan merupakan skor yang diperoleh dalam penelitian dengan menyebarkan 24 butir instrumen dalam skala interval. Setelah dilakukan rekapitulasi data, maka diperoleh skor tertinggi 11,5 dan terendah 10,7. Rata-rata hitung (mean) adalah 11,1 dengan standar deviasi 0,287 serta memiliki varian 0,0825 .

4. Data Kemampuan Menerima Informasi yang berada di kelas menggunakan Multimedia Animasi yang memiliki Motivasi Belajar Tinggi $\left(\mathrm{A}_{1} \mathrm{~B}_{2}\right)$

Data Kemampuan Menerima Informasi yang berada di kelas menggunakan Multimedia Animasi yang memiliki Motivasi Belajar Tinggi secara keseluruhan merupakan skor butir instrumen yang diperoleh dalam penelitian dengan menyebar 24 butir instrumen dalam skala 
interval. Setelah dilakukan rekapitulasi data, maka diperoleh skor tertinggi 16,5 dan terendah 12. Rata-rata hitung (mean) adalah 14,6 dengan standar deviasi 1,38 serta memiliki varian 1,90 .

5. Data Kemampuan Menerima Informasi yang berada di kelas menggunakan Multimedia Animasi yang memiliki Motivasi Belajar Rendah $\left(\mathrm{A}_{2} \mathrm{~B}_{1}\right)$

Data Kemampuan Menerima Informasi yang berada di kelas menggunakan Multimedia Animasi yang memiliki Motivasi Belajar Rendah secara keseluruhan merupakan skor butir instrumen yang diperoleh dalam penelitian dengan menyebar 24 butir instrumen dalam skala interval. Setelah dilakukan rekapitulasi data, maka diperoleh skor tertinggi 11,6 dan terendah 10,8.. Rata-rata hitung (mean) adalah 11,27 dengan standar deviasi 0,29 serta memiliki varian 0,083.

6. Data Kemampuan Menerima Informasi yang berada di kelas menggunakan Multimedia Animasi yang memiliki Motivasi Belajar Tinggi $\left(\mathrm{A}_{2} \mathrm{~B}_{2}\right)$

Data Kemampuan Menerima Informasi yang berada di kelas menggunakan Multimedia Animasi yang memiliki Motivasi Belajar Tinggi secara keseluruhan merupakan skor butir instrumen yang diperoleh dalam penelitian dengan menyebar 24 butir instrumen dalam skala interval. Setelah dilakukan rekapitulasi data, maka diperoleh skor tertinggi 19,2 dan terendah 13,4.. Rata-rata hitung (mean) adalah 15,98 dengan standar deviasi 1,65 serta memiliki varian 2,71.

Setelah dilakukan uji persyaratan analisis, dan hasil analisis perhitungan menunjukkan bahwa sampel berdistribusi normal dan homogennya maka selanjutnya dapat dilakukan uji hipotesis penelitian. Pengujian hipotesis penelitian dilakukan dengan menggunakan analisis varian (ANAVA) dua arah. Analisis ini digunakan untuk menguji perbedaan pengaruh utama (main effect) dan pengaruh interaksi (interaction effect) variable bebas yaitu Pengaruh Pembelajar Berbasis Presentasi Multimedia dan Motivasi Belajar terhadap Kemampuan Menerima Informasi.

Adapun hasil analisis menggunakan ANAVA dua arah dapt dilihat pada tabel dibawah ini.

Tabel 2. Tabel Hasil Perhitungan ANAVA Dua Arah

\begin{tabular}{|c|c|c|c|c|c|}
\hline $\mathrm{SV}$ & $\mathrm{dk}$ & $\mathrm{JK}$ & $\mathrm{RK}=\mathrm{JK} / \mathrm{db}$ & $\mathrm{Fh}=\mathrm{Rk} / \mathrm{RKD}$ & Ftabel \\
\hline $\mathrm{MB}$ & 1 & 197,90 & 197,90 & 105,71 & 4.0 \\
\hline $\mathrm{KMI}$ & 1 & 31,596 & 31,596 & 16,88 & 4.0 \\
\hline Interaksi & 1 & 9,178 & 9,178 & 6,28 & 4.0 \\
\hline
\end{tabular}




\begin{tabular}{|c|c|c|c|c|c|} 
Dalam & 56 & 104,84 & 1,87 & ---- & \\
\hline Total Reduksi & 59 & 322,59 & & & \\
\hline
\end{tabular}

Keterangan: Signifikansi pada taraf $\alpha: 0,05$

Setelah memperhatikan tabel hasil analisis varian dua arah di atas maka dapat disimpulkan bahwa:

1. Hipotesis nol $\left(\mathrm{H}_{0}\right)$ yang menyatakan bahwa Pembelajaran Berbasis Presentasi Multimedia dengan Animasi tidak berbeda dengan Pembelajaran Berbasis Presentasi Multimedia dengan Gambar ditolak, karena $F_{\text {hitung }}$ adalah 105,71 $>F_{\text {tabel }}(0,05: 56: 1)=4$. Sehingga dapat disimpulkan bahwa terdapat perbedaan antara Pembelajaran Berbasis Presentasi Multimedia dengan Animasi dan Pembelajaran Berbasis Presentasi Multimedia dengan Gambar terhadap kemampuan menerima informasi.

2. Hipotesisi nol $\left(\mathrm{H}_{0}\right)$ yang menyatakan bahwa motivasi belajar rendah tidak berbeda dengan motivasi tinggi ditolak. Karena $\mathrm{F}_{\text {hitung }}$ adalah 16,88> $\mathrm{F}_{\text {tabel(0,05:56:1) }}=4$. Sehingga dapat disimpulkan bahwa terdapat perbedaan antara motivasi belajar rendah dengan motivasi tinggi terhadap kemampuan menerima informasi.

3. Hipotesisi nol $\left(\mathrm{H}_{0}\right)$ yang tidak ada interaksi antara Pembelajaran Berbasis Presentasi Multimedia dan Motivasi Belajar siswa ditolak. Karena $\mathrm{F}_{\text {hitung }}$ adalah 6,28 $>F_{\text {tabel (0,05:56:1) }}=4$. Sehingga dapat disimpulkan bahwa terdapat perbedaan interaksi antara pembelajaran berbasis presentasi multimedia dan motivasi belajar terhadap kemampuan menerima informasi.

Pembahasan hasil penelitian pengaruh pembelajaran berbasis multimedia dan motivasi belajar terhadap kemampuan menerima informasi adalah sebagai berikut.

1. Hipotesis $A_{1} \neq A_{2}$ yang menyatakan bahwa kemampuan menerima informasi siswa pada kelas yang menggunakan pembelajaran dengan gambar berbeda dengan kelas yang menggunakan pembelajaran dengan animasi diterima.

Dilihat dari sudut pandang perkembangan anak, objek penelitian memiliki kemampuan kognitif yang telah mencapai tahap pra operasional konkrit yang memiliki berbagai kemampuan antara lain, anak sudah mengerti adanya konsep kekekalan objek, mampu menggambarkan secara menyeluruh ingatan, pengalaman, dan objek yang dialami, mampu melihat dari berbagai macam segi, mampu menyatukan benda-benda yang mempunyai kesamaan dalam satu dimensi, mampu memasangkan satu-satu dengan baik dan mengerti soal kekekalan dengan baik, mengerti urutan 
ruang dengan melihat interval jarak suatu benda atau kejadian, mereka sudah mampu mengerti relasi urutan waktu (sebelum dan sesudah), dan juga koordinasi dengan waktu (panjang dan pendek), mampu lebih mendalam melihat sebab suatu kejadian, mamu mengantisipasi sesuatu dengan jumlah yang banyak, mampu menghubungkannya berdasarkan asal melekatkan satu kalimat dengan kalimat yang lain.

Dari uraian di atas dapat disimpulkan bahwa sistem perkembangan pemikiran yang didasarkan pada aturan-aturan tertentu yang logis. Kemampuan anak berpikir logis menunjukkan bahwa anak mampu memecahkan persoalan-persoalan konkrit, seperti mengklasifikasikan, mengurutkan, dan memecahkan masalah, perhatian yang lama, tertarik pada kesimpulan dan logika akhir, dan memperluas pengetahuan dan ketertarikan.

Perkembangan kognitif pada objek penelitian di atas memberikan gambaran bahwa potensi anak untuk belajar melalui multimedia sangat memungkinkan. Jika didasarkan pada pengalaman anak terhadap media yang digunakan maka optimalisasi penerimaan informasi pada multimedia presentasi dapat dilakukan dengan menggunakan media yang menghasilkan suara dan penglihatan. Artinya, bentuk yang lebih dinamis dan kompleks dari media memberikan kesempatan anak untuk mendapatkan informasi yang lebih.

Secara teoritis fungsi indra berpengaruh dalam penerimaan informasi. Indra-indra tersebut akan menerima rangsangan melalui media yang digunakan dalam pembelajaran. Media-media tersebut akan menghantarkan materi pembelajaran berupa suara dan gambar yang dikombinasikan juga dengan tulisan kepada siswa agar mampu dipahami.

Semakin banyak media yang digunakan dalam pembelajaran akan semakin mempermudah siswa dalam menerima materi belajar. Oleh karena itu, indra yang berfungsi menerima rangsangan akan bekerja optimal dalam proses pembelajaran.

Perpaduan gambar dan suara akan menambah optimalisasi penerimaan informasi dari proses belajar. Hal ini disebabkan mata sebagai organ visual dan telinga sebagai organ audio akan bekerja proporsional menerima informasi dan akan diolah dengan cepat di dalam otak. Berbeda halnya ketika hanya menggunakan gambar saja. Penumpukan informasi pada organ visual memberikan banyak waktu untuk diolah kembali di dalam memori.

Di samping itu terjadi perbedaan bentuk media yang digunakan. Perbedaan terjadi pada materi yang mengedepankan proses. Informasi materi proses terjadinya sesuatu lebih mudah diterima jika divisualisasikan dengan 
simulasi seperti kejadian sebenarnya dibandingkan dengan gambar yang hanya diam semata.

Dari paparan di atas jelas sekali terjadi perbedaan dua jenis media yang digunakan terhadap kemampuan siswa dalam menerima informasi materi belajar. Sekolah yang telah menggunakan media pembelajaran dengan suara dan gambar animasi akan semakin mengoptimalkan kemampuan siswanya dalam menerima informasi materi untuk tercapainya hasil belajar yang maksimal. Sementara sekolah yang kurang mengoptimalkan media pembelajaran, penerimaan informasi siswanya terhadap materi belajar akan lebih lambat yang menyebabkan hasil belajarnya tidak maksimal.

Dapat disumpulkan bahwa optimalisasi fungsi indra dalam pembelajaran melalui media belajar sangat diharapkan. Hal ini bertujuan untuk mengoptimalkan kemampuan menerima informasi siswa sehingga dapat meningkatkan hasil belajarnya.

2. Hipotesis Interaksi $A \times B \neq 0$ yang menyatakan bahwa terdapat interaksi antara pembelajaran berbasis presentasi multimedia dan motivasi belajar terhadap kemampuan menerima informasi pada siswa kelas III Sekolah Dasar diterima.

Walaupun motivasi belajar mempengaruhi kemampuan menerima informasi, pengaruhnya akan beragam bila penggunaan multimedia pembelajaran presentasi digunakan dalam proses belajar mengajar.

Secara umum karakteristik psikologis dari objek penelitian bahwa anak berada pada kondisi dimana mulai terjadinya kompetisi. Disinilah anak belajar menguasai kemampuan kognitif dan sosial yang penting. Mereka memiliki kemampuan baru, dan mereka juga belajar, mereka memperoleh pengakuan dari orang dewasa dalam tugas akademik. Ketika mereka melakukan sesuatu mereka mendapatkan pujian untuk menyelesaikannya. Anak mulai menunjukkan pola kerja keras, melakukan dengan tekun pekerjaan yang keras, dan menempatkan pekerjaan sebagai kesenangan.

Karakteristik objek penelitian di atas memberikan gambaran bahwa untuk memperoleh pengakuan anak berusaha menunjukkan kapasistasnya kepada orang lain. Dorongan ini menjadi penting ketika dibuka kesempatan untuk menghasilkan sesuatu yang posistif dalam proses belajar. Dengan demikian adanya hubungan antara dorongan eksistesial pada anak mempengaruhi produktivitasnya.

Di samping itu, anak akan merasa terlibat dan ekspresif ketika dihadapkan pada suasana yang dinamis. Hal ini didukung faktor psikologis sosial anak dimana mereka belajar mengenal emosi mereka melalui interaksinya dengan orang lain. Walaupun perlu di sadari bahwa mereka sebelumnya 
telah memiliki berbagai emosi. Ekspresi dari emosi-emosi ini menunjukkan bahwa anak merasa terlibat dalam interaksi dengan media.

Di sisi lain anak bebas mengarahkan kembali energinya pada pengejaranpengejaran konkret yang bisa diterima secara sosial. Artinya, kekonkretan bentuk dari media mempengaruhi energi untuk bergerak mendapatkan sesuatu.

Dari paparan di atas jelas bahwa pada kelas yang menggunakan multimedia animasi dan suara, terdapat perbedaan pada siswa yang memiliki motivasi rendah dan tinggi. Kemampuan menerima informasi pada siswa yang memiliki motivasi belajar tinggi cenderung lebih unggul dari pada siswa yang memiliki motivasi rendah.

Motivasi belajar yang rendah dan tinggi cenderung berbeda dalam penggunaan multimedia animasi dan suara. Konsekwensinya, kemampuan menerima informasi berbeda antara kedua kelompok tersebut. Dimana siswa yang memiliki motivasi tinggi cenderung kemampuan menerima informasinya lebih baik dari pada siswa yang memiliki motivasi rendah.

Sedangkan pada kelas yang menggunakan mutimedia gambar, juga terdapat perbedaan dalam motivasinya. Sama halnya pada kelompok sebelumnya, pada kelompok ini siswa yang memiliki motivasi tinggi cenderung lebih baik dari pada siswa yang memiliki motivasi rendah. Walaupun secara keseluruhan kelas ini kelompok ini memiliki motivasi belajar yang lebih rendah dari kelompok lainnya.

3. Hipotesis $A_{1} B_{1} \neq A_{2} B_{1}$ yang menyatakan bahwa kemampuan menerima informasi pada kelas dengan pembelajaran yang menggunakan gambar dan memiliki motivasi belajar rendah berbeda dengan kemampuan menerima informasi pada kelas dengan pembelajaran yang menggunakan animasi dan memiliki motivasi belajar rendah diterima.

Terdapat perbedaan kemampuan menerima informasi dari siswa yang memiliki motivasi rendah di dua kelas yang berbeda. Pada siswa yang memiliki motivasi rendah di kelas yang menggunakan multimedia animasi dan suara cenderung lebih unggul dari pada kelas yang menggunakan multimedia gambar.

Seperti yang telah dijelaskan di atas, bahwa optimalisasi fungsi indra akan mendukung penerimaan informasi. Adanya pengaruh tersebut menjadi faktor pendukung utama adanya perbedaan kemampuan menerima informasi di dua kelompok penelitian. Artinya optimalisasi indra menjadi penting dalam masalah ini. Di samping itu, bentuk yang lebih konkrit dari materi yang disajikan dengan menggunakan animasi meningkatkan kemampuan menerima informasi pada siswa dengan motivasi belajar 
rendah. Dengan demikian terbangunnya pemikiran logis pada siswa karena kekonkritan materi yang disajikan.

4. Hipotesis $A_{1} B_{2} \neq A_{2} B_{2}$ yang menyatakan bahwa kemampuan menerima informasi pada kelas dengan pembelajaran yang menggunakan gambar dan memiliki motivasi belajar tinggi berbeda dengan kemampuan menerima informasi pada kelas dengan pembelajaran yang menggunakan animasi dan memiliki motivasi belajar tinggi diterima.

Pada hasil penelitian diperoleh bukti bahwa kemampuan menerima informasi akan didukung oleh motivasi belajar. Motivasi belajar tinggi akan mendukung kemampuan siswa dalam menerima informasi yang tinggi pula.

Siswa dengan motivasi belajar tinggi akan selalu terdorong untuk ingin tahu sesuatu yang baru. Rasa ingin tahu inilah yang memacunya untuk terus mengeksplorasi materi dengan tujuan pencarian makna yang lebih dalam. Sesuatu yang baru memacu siswa untuk menyesuaikan emosinya agar bisa diterima, disinilah egonya muncul. Ketika kondisi ini sudah mulai muncul, mereka ingin mengetahui lebih banyak untuk mendapatkan pengakuan dari orang dewasa. Oleh karena itu, kemauan untuk belajar yang tinggi akan berdampak pada kemampuannya menerima informasi.

Sama halnya dengan hipotesis sebelumnya, bahwa terdapat perbedaan kemampuan menerima informasi dari dua kelompok penelitian yang dilakukan. Namun, siswa dengan motivasi tinggi yang mendapatkan pembelajaran multimedia animasi dan suara lebih tinggi dibandingkan siswa dengan motivasi tinggi yang berada pada kelas yang menggunakan multimedia gambar.

Berbicara tentang media tak terlepas dari indra. Namun, disamping itu, kedinamisan model penyampaian materi akan menimbulkan misteri dari setiap proses yang akan dilalui. Sehingga, keinginan untuk mengetahui proses selanjutnya akan memberikan motivasi belajar yang tinggi dengan harapan mendapatkan informasi yang lebih banyak.

\section{KESIMPULAN}

Berdasarkan hasil penelitian yang telah dilakukan terhadap siswa Kelas III Sekolah Dasar di SD Islam Plus Bina 45 Kota Pontianak, maka dapat ditarik kesimpulan sebagai berikut.

1. Terdapat pengaruh kemampuan menerima informasi siswa antara yang berada di kelas yang menggunakan multimedia animasi dengan kelas yang menggunakan multimedia gambar. Kemampuan menerima informasi pada siswa dengan multimedia animasi lebih unggul dari pada siswa dengan multimedia gambar. 
2. Terdapat interaksi antara pembelajaran berbasis presentasi multimedia dan motivasi belajar terhadap kemampuan menerima informasi. Dengan demikian dapat dinyatakan bahwa untuk meningkatkan kemampuan menerima informasi bagi anak yang memiliki motivasi belajar rendah maupun tinggi adalah dengan multimedia animasi. Sedangkan pada kelas dengan presentasi multimedia gambar kemampuan menerima informasinya lebih rendah, baik yang memiliki motivasi belajar rendah maupun tinggi.

3. Ternyata, kemampuan menerima informasi pada kelas dengan pembelajaran yang menggunakan gambar dan memiliki motivasi belajar rendah berbeda dengan kemampuan menerima informasi pada kelas dengan pembelajaran yang menggunakan animasi dan memiliki motivasi belajar rendah. Dengan demikian dapat dinyatakan bahwa kelas dengan multimedia animasi dapat meningkatkan kemampuan menerima informasi dari pada kelas dengan multimedia gambar.

4. Ternyata, kemampuan menerima informasi pada kelas dengan pembelajaran yang menggunakan gambar dan memiliki motivasi belajar tinggi berbeda dengan kemampuan menerima informasi pada kelas dengan pembelajaran yang menggunakan multimedia animasi dan memiliki motivasi belajar tinggi. Dengan demikian dapat dinyatakan bahwa kelas dengan multimedia animasi dapat meningkatkan kemampuan menerima informasi pada siswa yang memiliki motivasi belajar tinggi dari pada kelas dengan multimedia gambar.

\section{SARAN}

Berdasarkan hasil penelitian dan pembahasan dalam penelitian ini, maka ada beberapa saran yang akan diusulkan kepada sekolah, guru, instansi terkait, dan siswa.

\section{Sekolah}

Dalam rangka usaha untuk meningkatkan hasil belajar dengan meingkatkan kemampuan menerima informasinya disarankan kepada sekolah, khususnya Sekolah Dasar agar: a)menyiapkan sarana-prasarana yang mendukung dalam pembelajaran dengan multimedia; b)sekolah sebaiknya menyiapkan perangkat khusus yang digunakan sebagai sumber belajar bagi anak dalam bentuk digital; c)sekolah diharapkan berperan aktif dalam mendukung guru menyiapkan bahan ajar yang terdigitasi.

\section{Guru}

Usaha dalam memaksimalkan potensi pembelajaran berbasis multimedia, disarankan kepada guru agar: a)meningkatkan kemampuannya dapat mengoperasikan perangat komputer dan program-programnya; b)membuat dan menyiapkan bahan ajar dalam bentuk multimedia. 


\section{Instansi Terkait}

Usaha dalam rangka meningkatkan kemampuan menerima informasi seyogyanya instansi terkait dalam hal ini kementerian Pendidikan Nasional dan Pemerintah Daerah ikut mendorong tersedianya fasisiltas yang memadai bagi proses belajar mengajar dan menyediakan perangkat lunak bagi guru dalam mengajar dengan multimedia serta melakukan pelatihan operasional dan penyiapan multimedia pembelajaran tersebut.

\section{DAFTAR RUJUKAN}

Arsyad, Azhar. Media Pembelajaran. Jakarta: Rajawali Pers, 2009.

Atkitson, Rita L., Richard C. Atkitson, Edward E. Smith, and Daryl J. Bem. Pengantar Psikologi. Alih bahasa: Widjaja Kusuma. Batam: Interaksara,.

Berk, Laura E. Development Through the Lifespan. USA: Allyn and Bacon, 2004.

Brewer, Jo An. Introduction to Early Childhod Education. Boston, USA: Allyn and Bacon, 2007.

Buzan, Tony. Mind Map. Alih bahasa:Susi Purwoko. Jakarta: Gramedia, 2006.

Carlson, Neilr. Psychology. Massachusets, USA: Allyn And Bacon, 1987.

Crain, William. Teori Perkembangan. Alih bahasa: Yudi Santoso. Yogyakarta: Pustaka Pelajar, 2007

Feldman, Robert S. Essentials of understanding Psychology. USA: McGraw Hill, 1989.

Gagne, Robert M. Prinsip-prinsip Belajar untuk Pengajaran. Alih bahasa: Abdillah Hanafidan Abdul Manan. Surabaya: Usaha Nasional, 1988.

Heinich, Robert, Michael Molenda, and James D. Russel, Instructional Media. Singapore: MacMillan, 1990

Johnson, Gregory. Creating Powerful Memory Alih bahasa: M. Jauhar. Jakarta: Prestasi Pustaka, 2009.

Kemp, Jerrold E. and Don C. Smellie, Planning, Producing, and Using Instructional Media. New York: Harper \& Row, 1989

Linsay, Peter H., and Donald A. Norman. Human Information Processing. New York, USA: Academic Press, 1977.

Mayer, Richard E. Multimedia Learning. Alih Bahasa: Teguh Wahyu Utomo. Yogyakarta: Pustaka Pelajar, 2009.

McGaugh, James L., Richard F. Thomson, and Thomas O. Nelson, Psychology I: An Experimental Approach. California, San Fransisco: Albion Publishing Company, 1977.

McDevitt, Teresa M., and Jeanne Ellis Ormrod. Child Development. New Jersey: Pearson Educational Inc, 2004. 
Morrow, Lesley Mandel. Literacy Development In the Early Years. USA: Allyn and Bacon, 1993.

Munadi, Yudhi. Media Pembelajaran. Jakarta: Gaung Persada Press, 2008.

Munir, Kurikulum berbasis Teknologi Informasi dan Komunikasi. Bandung: Alfabeta, 2008.

Papalia, Diane E., Sally W. Olds, and Ruth D. Feldman, Human Development. Singapore: McGraw Hill, 2008.

Richard M. Lerner, et al. Psychology. New York: Mac Millan Publishing Company, 1986.

Romiszowski, A J. The Selection and Use of Instructional Media. London: Kogan Page, 1988.

Sadiman, Arif S., et al. Media Pendidikan. Jakarta: Rajawali Pers, 2009.

Santrock, John W. Child Development. Texas, USA: Brown \& Benchmark, 1996.

Perkembangan Anak. Alih Bahasa: Mila Rachmawati dan Anna Kuswanti. Jakarta: Erlangga, 2007

Sarwono, Sarlito W. Pengantar Umum Psikologi. Jakarta: Bulan Bintang, 2003.

Schunk, Dale S., Paul R. Pintrich, and Judith L. Meece, Motivation in Education. New Jersey, USA: Pearson Education, 2008.

Siegler, Robert S. Children Thinking. New Jersey: Prentice Hall, 1991.

Slavin, Robert E. Psikologi Pendidikan. Alih bahasa: Marianto Samosir. Jakarta: Indeks, 2009

Smaldino, Sharon E., Deborah L. Lowther, and James D. Russel, Instructional Technology and Media for Learning. New Jersey, USA: Pearson Prentice Hall, 2008.

Solso, Robert L., Otto H. Maclin, and M. Kimberly Maclin. Psikologi Kognitif. Jakarta: Erlangga, 2008.

Suparno, Paul. Tori Perkembangan Kognitif Jean Piaget. Yogyakarta: Kanisius, 2001.

Suryanti, Perbandingan Hasil Belajar Matematika Siswa yang Menggunakan Media Tiga Dimensi dengan Media Gambar pada Kelas III Sekolah Dasar yayasan Perguruan Cikini Jakarta tahun 1990. Jakarta: FIP UNJ, 1991. Skripsi.

Thompson, Richard F., and Stepen A. Madigan. Memory: The Key to Consciousness. Alih bahasa: Setya Ambar Pratiwi. Jakarta: Transmedia, 2007.

Vasta, Ross, Marshal M Haith, and Scott A.Miller. Child Psychology. New York : John Willey \& Sons, 1999. 
Woolfolk, Anita. Educational Psychology. Alih bahasa: Helly Prajitno S dan Sri Mulyantini S. Yogyakarta: Pustaka Pelajar, 2009.

Wortman, Camille B., and Elizabeth F. Loftus, Psychology. New York, USA: Alfred A. Knopf, Inc, 1985.

Bloom's Taxonomy of Learning Domains, http://www.nwlink.com/ donclark/hrd/bloom.html

Multimedia http://www.wordiq.com/definition/Multimedia 19/10/2010

Multimedia,http://202.91.15.14/upload/files/9055_01-

Pengantar_MULTIMEDIA.pdf 19/10/2010

Multimedia http://ryanvsp.multiply.com/journal/item/1 19.10/2010

Sugiman. Pinsip-Prinsip Perkembangan anak usia Dini. 17/10/2010. http://www.infogue.com/viewstory/2008/10/24/prinsip_prinsip_perkemb angan_anak_usia_dini/?url=http://sugimanbengkulu.blogspot.com/2008/10/prinsip-prinsip-perkembangan-anakusia.html 